\title{
Host feeding behaviour of Dermacentor reticulatus males in relation to the transmission of pathogens
}

\author{
Katarzyna Bartosik ${ }^{1, A-F}{ }^{\oplus}$, Alicja Buczek ${ }^{1, A, C-F \oplus}$, Weronika Buczek ${ }^{1, D, F}{ }^{\text {, Alicja M. Buczek }}{ }^{1, D, F}$, \\ Dorota Kulina ${ }^{2, D, F} \oplus$, Agnieszka Koman-lżko ${ }^{1, D, F} \odot$ \\ ${ }^{1}$ Chair and Department of Biology and Parasitology, Medical University, Lublin, Poland \\ ${ }^{2}$ Department of Basic Nursing and Medical Teaching, Medical University, Lublin, Poland \\ A - Research concept and design, B - Collection and/or assembly of data, C - Data analysis and interpretation, \\ $D$ - Writing the article, E - Critical revision of the article, F - Final approval of article
}

Bartosik K, Buczek A, Buczek W, Buczek AM, Kulina D, Koman-lżko A. Host feeding behaviour of Dermacentor reticulatus males in relation to the transmission of pathogens. Ann Agric Environ Med. 2019; 26(2): 227-230. doi: 10.26444/aaem/105402

\begin{abstract}
Introduction. The three-host Dermacentor reticulatus tick transmits many pathogens, which are introduced into the host with saliva during feeding.

Material and methods. The aim of present study was to analyse the behaviour of males of this species on the host in homogeneous sex groups comprising 15 (group I) and 30 (group II) male specimens and in a mixed group composed of 15 males and 15 females (group III).

Results. Although the dynamics of attachment of the males to host skin slightly differed between these three groups, there was no statistically significant difference in the duration of the attachment process. The duration of host attachment of the males in groups I, II, and III at $18 \pm 2{ }^{\circ} \mathrm{C}$ and $50 \pm 2 \% \mathrm{RH}$ was $2.43 \pm 2.46,7.75 \pm 11.85$, and $9.07 \pm 10.97$ days, respectively. After 7-9-day feeding, the male engorgement weight (MEW) was similar, regardless of the size of the group and the presence or absence of females on the host. Tick males ingest a small amount of host blood. The value of MEW in the three groups did not differ statistically from the weight of unengorged specimens.

Conclusions. The host feeding behaviour of $D$. reticulatus males and their effective feeding suggest that they may play a role in transmission of pathogens and non-pathogenic microorganisms with tick saliva during blood meal ingestion. Clinical and laboratory diagnostics of human and animal tick-borne diseases as well as epidemiological studies should consider the possibility of pathogen transmission by males of metastriata ticks, which feed on the host for several days.
\end{abstract}

Key words

Ticks, Dermacentor reticulatus, host feeding behaviour, attachment of the males, male engorged weight, pathogen transmission

\section{INTRODUCTION}

Ticks are obligate human and animal parasites in various climatic zones. The components of their saliva secreted during feeding can cause non-systemic skin lesions and systemic reactions in the host with their range, intensity, and clinical picture depending on the physiological features of the tick-host system. However, the most harmful effects of tick parasitism are associated with host infection with tick-borne pathogens. In the group of arthropods, ticks exhibit high competence to transmit various microorganisms, including pathogens that pose a great threat to human health and companion animals.

Monitoring of the occurrence of ticks conducted in different regions indicates an increase in the number and range of the spread of tick species with high epidemiological importance $[1,2,3,4,5]$. Consequently, the risk of tick infestations of hosts and infections with tick-borne pathogens is increasing. Therefore, investigations into the behaviour of different developmental stages of ticks on the host are becoming increasingly important and necessary. They can provide detailed knowledge about the biology of ticks and the mechanisms of pathogen circulation in nature.

Address for correspondence: Katarzyna Bartosik, Medical University, Lublin, Poland E-mail: katarzyna.bartosik@umlub.pl

Received: 18.02.2019; accepted: 06.03.2019; first published: 04.04.2019
The study investigates the process of host attachment and feeding in Dermacentor reticulatus males, which often attack companion animals in northern and central Europe $[6,7$, $8,9,10,11]$. The tick can also parasitize humans $[12,13,14]$. Similar to other representatives of metastriata ticks, the adult D. reticulatus stages copulate on the host [15].

\section{MATERIALS AND METHOD}

Hungry adult stages (males and females) of D. reticulatus were collected by the flagging method in meadows located near Lublin, eastern Poland, during the peak activity of the species [16, 17]. Before laboratory analyses, the specimens were kept in glass containers at room temperature (approx. $20 \pm 2{ }^{\circ} \mathrm{C}$ ) and $80-90 \%$ humidity, i.e. in conditions favourable for this species [16]. The experiments involved 60 males and 15 females of D. reticulatus. Three native albino New Zealand rabbits (Oryctolagus cuniculus) with a body weight in the range of 3-3.5 kg were the tick hosts. The animals were kept at a temperature of approx. $18 \pm 2{ }^{\circ} \mathrm{C}$ and $50 \pm 2 \%$ humidity, in compliance with all ethical rules in force in the European Union. Two rabbits were intended for observation of the course of attachment and feeding of males in the absence of females, whereas the behaviour of male ticks in the presence of females of the same species on the host was observed on 
the third animal. A canvas sack with the ticks was placed on a $78.5 \mathrm{~cm}^{2}$ area of shaved skin of the rabbits'.

Before placing on the rabbit skin, hungry D. reticulatus males were weighed using a RADWAG XA 110 analytical balance with an accuracy of $0.0001 \mathrm{~g}$. Either 15 or 30 males were placed on one host. To compare whether the behaviour of the males on the host in the absence of females differed from their behaviour in the presence of representatives of the other gender, $15 \mathrm{D}$. reticulatus females were placed on the skin of another host, together with 15 males.

The behaviour of the males from the homogeneous gender groups and in the presence of females was assessed every half hour for the first eight hours of the experiments, and then every 24 hours at the same time of day, until the specimens detached from the skin of the rabbits. After attachment to the skin, tweezers were used to check whether the tick's hypostome was firmly anchored. The dynamics of males' attachment to the host skin was observed. Since some specimens changed the attachment site and the initial attachment determined, i.e. the moment when the specimens were firmly attached to the host skin. These observations facilitated determination of the time point of initiation of feeding in the homogeneous gender groups and in the group with females (attachment period, AP). Since the males changed their attachment site, it was impossible to determine the precise duration of their feeding. Males that had detached from the host skin were collected and weighed on an analytical balance to determine the male engorgement weight (MEW).

\section{RESULTS AND DISCUSSION}

Ingestion of host's blood by larvae, nymphs, and adult stages is indispensable for the development of successive stages, mating, and reproduction. The behaviour on the host, attachment, and feeding are studied mainly in tick nymphs and females, which usually infest large domestic and wild animals as well as humans. The prevalence of pathogens in these stages is typically higher than in the other forms, and thus they are the major vectors of tick-borne diseases. Nymphs and females infect the host during feeding which lasts from several to a dozen or so days during their seasonal activity, depending on, e.g. the stage and species of the tick $[18,19,20]$, intensity of invasion $[20,21]$, and physiological status of the host $[19,20,22]$.

To date, considerably less attention has been paid to the behaviour of males of ixodid tick species characterised by high epidemiological importance and competence to transmit pathogens during feeding. The present study of the behaviour of $D$. reticulatus males on the host are in line with researchers' interest in identification of routes of tick pathogen transmission to potential hosts. Research on the parasitic phase in male ixodid ticks has become more relevant since tick-borne pathogens were detected in specimens removed from a host [13, 23, 24, 25, 26]. For instance, Földvári et al. [13] identified Rickettsia slovaca and Rickettsia raoultii in D. reticulatus and D. marginatus males removed from the skin of patients with tick-borne lymphadenopathy (TIBOLA) symptoms.

In the current study, attachment of the D. reticulatus males to the host skin was noted already at $0.5 \mathrm{~h}$ after they were placed on the host. Within two hours after the beginning of the experiments, $60 \%, 56.6 \%$, and $53.3 \%$ of males were attached in the groups of 15 and 30 males, and in the mixed group consisting of 15 males and 15 females, respectively. Most of the males in the first (80\%), second (76.6\%), and third (60\%) group were attached to the host after $2.5 \mathrm{~h}, 4.5$ $\mathrm{h}$, and $4 \mathrm{~h}$, respectively. In group I, $100 \%$ of the males on the host were attached after $7 \mathrm{~h}$. In turn, a similar percentage of males that were firmly attached to the host skin in groups II and III were recorded only after $24 \mathrm{~h}$.

Regardless of the differences in the dynamics of male attachment to the host, the present study of the behaviour of $D$. reticulatus males demonstrates that the number of males on the host does not exert a statistically significant effect ( $p=0.6051)$ on the period of attachment to the skin (Tab. 1). The attachment period in the case of males infesting the host in the absence of females, i.e. in the groups of 15 and 30 specimens, was $2.43 \pm 2.46$ and $7.75 \pm 11.85$ days, respectively. The statistical test did not reveal a statistically significant difference in the dynamics of male attachment in the homogeneous gender groups and in the group comprising males and females (Tab. 1). Some males in the homogeneous gender group changed their attachment place mainly within the first hours after placement on the host skin. The methodology used in this study (i.e. unlabelled specimens) and their schedule (checking the course of the experiments only at specific intervals) did not allow determination of whether all males and at what frequency the specimens changed the host attachment site before feeding. In contrast to the males from all the experimental groups, the D. reticulatus females in the mixed group were attached at the same site until full engorgement and detachment from the host skin.

As reported by Balashov [18] and Oliver [27], in metastriata ticks also represented by $D$. reticulatus, the development of gender cells after the transformation of male nymphs into males is halted in primary spermatocytes in late prophase. Further development of germ cells proceeds only when males attach to the host $[15,18,27]$. Blood ingestion by male ticks stimulates the endocrine system to secrete hormones, which influence spermogenesis and mating $[18,28]$. In Dermacentor occidentalis males, morphological, histological, and cytological changes in testes were detected as early as one day after initial attachment. The males were able to mate and inseminate females at days 4-6 (mean 5) after attachment to the host [29].

Table 1. The attachment period - AP (h) of Dermacentor reticulatus males in the groups studied

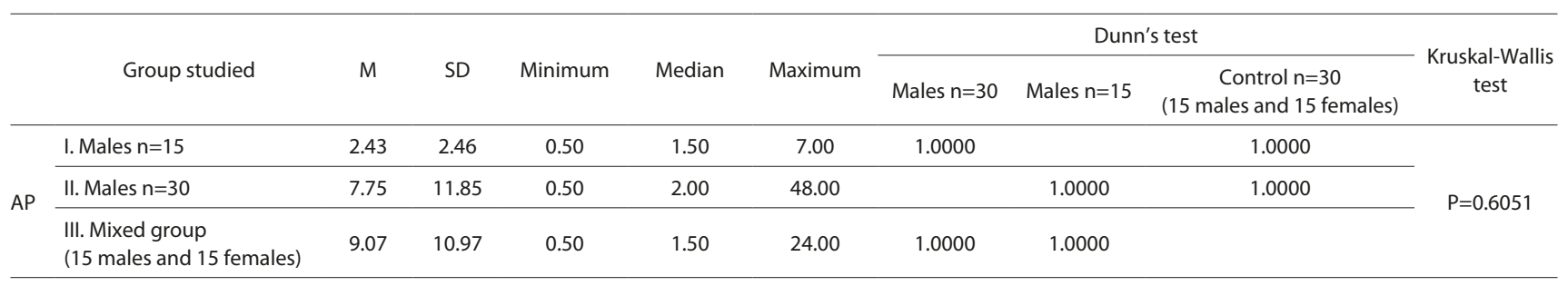

M - mean, SD - standard deviation 


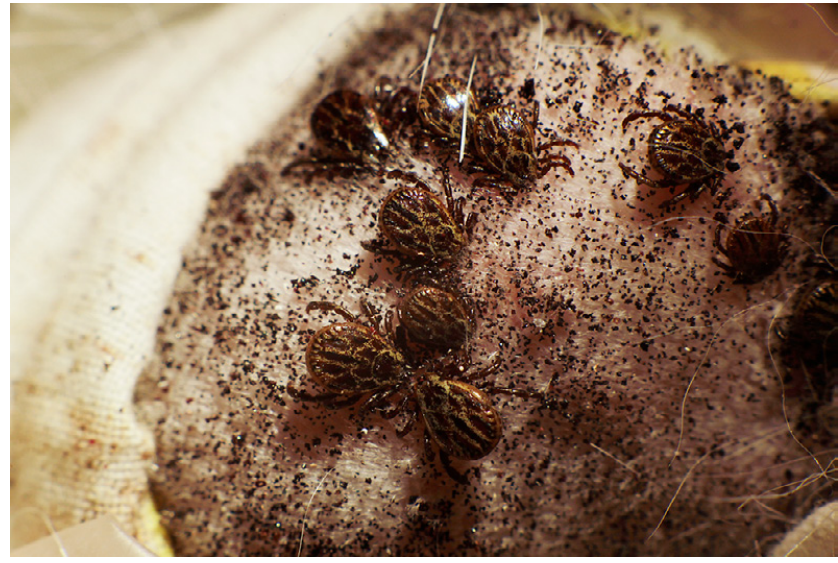

Figure 1. Males of Dermacentor reticulatus feeding on rabbit (Oryctolagus cuniculus) in the homogeneous gender group $(n=15)$

Hungry D. reticulatus males in the homogeneous infestations attached to the host at various distances from each other (Fig. 1). A similar mode of male attachment was observed in the presence of partially engorged females. The males attached and began feeding usually at a certain distance from the females (Fig. 2). On the first day, the behaviour of the males in this group was similar to that in the homogeneous gender groups. After ingestion of the portion of blood required for the development of the male genital organs, and for achievement of sexual potential (i.e. at days 7-9 after the placement on the host), the males detached from the host skin, migrated towards the feeding females, and mated with them.

As shown in the present study, D. reticulatus males ingest a small amount of host blood, regardless of their density on the host and the presence or absence of females on the same host. The male engorgement weight was not statistically significantly different from the weight of hungry specimens collected from the vegetation, i.e. from $0.00521 \mathrm{~g}-$ $0.00789 \mathrm{~g}$ (mean $0.006452 \mathrm{~g}$ ) (Tab. 2). Differences in the male engorgement weight (MEW) between the three groups were not statistically significant (Tab. 2). In turn, Rhipicephalus appendiculatus males were reported to double their weight prior to achievement of insemination competence after 4-6 days of feeding on pigs [30].

The several-day long feeding of $D$. reticulatus males creates an opportunity to transmit many pathogens interacting with the tick (vector) into the host. The duration of attachment and feeding on the host by hard ticks required for pathogen transmission is shorter than 15 min in the case of Powassan virus [31], from $4-96 \mathrm{~h}$ for various bacteria, and 7-18 days

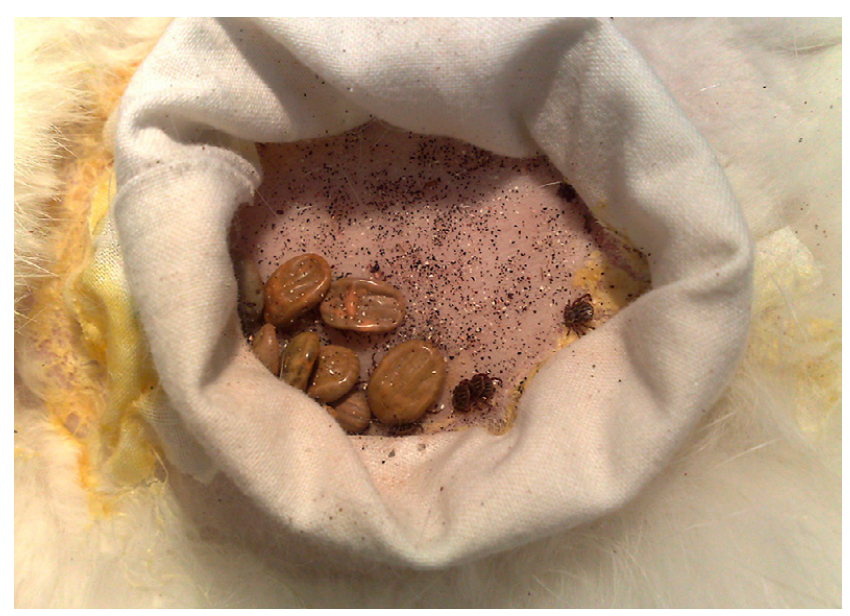

Figure 2. Males and females of Dermacentor reticulatus feeding on rabbit (Oryctolagus cuniculus) in group of 15 males and 15 females

for Babesia species [32]. Alekseev and Chunikhin [33] have confirmed the presence of TBE viruses in the saliva of Dermacentor and Ixodes males and females at the beginning of feeding. When a tick male is found in host skin, complete laboratory and clinical diagnostics should be employed to confirm or exclude the pathogen infection.

\section{CONCLUSIONS}

The results of this research indicate that the behaviour of D. reticulatus males on the host (attachment and feeding) predisposes them to transmission of pathogens and nonpathogenic microorganisms present in tick saliva in various periods of the parasitic phase. The importance of metastriata ticks in pathogen transmission should be underlined during epidemiological studies and diagnostics of human and animal tick-borne diseases. Complete elucidation of the competence of male ticks for transmission of microorganisms requires further field and laboratory studies.

\section{REFERENCES}

1. Bullova E, Lukáň M, Stanko M, Pet'ko B. Spatial distribution of Dermacentor reticulatus tick in Slovakia in the beginning of the 21st century. Vet Parasitol. 2009; 165(3-4): 357-360.

2. Nowak-Chmura M. Fauna of Ticks of Central Europe. Wydawnictwo Naukowe Uniwersytetu Pedagogicznego, Kraków, 2013 (in Polish).

3. Buczek A, Bartosik K, Wiśniowski L, Tomasiewicz K. Changes in population abundance of adult Dermacentor reticulatus (Acari:

Table 2. The male engorgement weight - MEW (g) of Dermacentor reticulatus males in the groups studied

\begin{tabular}{|c|c|c|c|c|c|c|c|c|c|c|c|}
\hline & \multirow[b]{2}{*}{ Group studied } & \multirow[b]{2}{*}{$M$} & \multirow[b]{2}{*}{ SD } & \multirow[b]{2}{*}{ Minimum } & \multirow[b]{2}{*}{ Median } & \multirow[b]{2}{*}{ Maximum } & \multicolumn{4}{|c|}{ Dunn's test } & \multirow[b]{2}{*}{$\begin{array}{c}\text { Kruskal-Wallis } \\
\text { test }\end{array}$} \\
\hline & & & & & & & Males $n=30$ & Males $n=15$ & $\begin{array}{c}\text { Control } n=30 \\
(15 \text { males and } \\
15 \text { females) }\end{array}$ & $\begin{array}{l}\text { Hungry } \\
\text { males }\end{array}$ & \\
\hline \multirow{3}{*}{ MEW } & I. Males $n=15$ & 0.0077 & 0.0020 & 0.0046 & 0.0076 & 0.0103 & 1.0000 & & 1.0000 & 0.2903 & \multirow{3}{*}{$P=0.0964$} \\
\hline & II. Males $n=30$ & 0.0075 & 0.0034 & 0.0010 & 0.0078 & 0.0137 & & 1.0000 & 1.0000 & 0.0804 & \\
\hline & Hungry males & 0.0065 & 0.0007 & 0.0052 & 0.0064 & 0.0078 & 0.0804 & 0.290 & 0.3266 & & \\
\hline
\end{tabular}

M - mean, SD - standard deviation 
Amblyommidae) in long-term investigations in eastern Poland. Ann Agric Environ Med. 2013; 20(2): 269-272.

4. Medlock JM, Hansford KM, Bormane A, Derdakova M, Estrada-Peña A, George JC, et al. Driving forces for changes in geographical distribution of Ixodes ricinus ticks in Europe. Parasit Vectors 2013; 6: 1 .

5. Földvári G, Široký P, Szekeres S, Majoros G, Sprong H. Dermacentor reticulatus: a vector on the rise. Parasit Vectors 2016; 9: 314

6. Földvári G, Farkas R. Ixodid tick species attaching to dogs in Hungary. Vet Parasitol. 2005; 129(1-2): 125-131.

7. Zygner W, Jaros S, Wędrychowicz H. Prevalence of Babesia canis, Borrelia afzelii, and Anaplasma phagocytophilum infection in hard ticks removed from dogs in Warsaw (central Poland). Vet Parasitol. 2008; 153(1-2): 139-142.

8. Reye AL, Stegniy V, Mishaeva NP, Velhin S, Hübschen JM, Ignatyev G, Muller CP. Prevalence of tick-borne pathogens in Ixodes ricinus and Dermacentor reticulatus ticks from different geographical locations in Belarus. PLoS One. 2013; 8(1): e54476.

9. Beck S, Schreiber C, Schein E, Krücken J, Baldermann C, Pachnicke S, von Samson-Himmelstjerna G, Kohn B. Tick infestation and prophylaxis of dogs in northeastern Germany: a prospective study. Ticks Tick Borne Dis. 2014; 5(3): 336-342.

10. Mierzejewska EJ, Welc-Falęciak R, Karbowiak G, Kowalec M, Behnke JM, Bajer A. Dominance of Dermacentor reticulatus over Ixodes ricinus (Ixodidae) on livestock, companion animals and wild ruminants in eastern and central Poland. Exp Appl Acarol. 2015; 66(1): 83-101.

11. Król N, Obiegala A, Pfeffer M, Lonc E, Kiewra D. Detection of selected pathogens in ticks collected from cats and dogs in the Wrocław Agglomeration, South-West Poland. Parasit Vectors 2016; 9: 351.

12. Bartosik K, Sitarz M, Szymańska J, Buczek A. Tick bites on humans in the agricultural and recreational areas in south-eastern Poland. Ann Agric Environ Med. 2011; 18(1): 151-157.

13. Földvári G, Rigó K, Lakos A. Transmission of Rickettsia slovaca and Rickettsia raoultii by male Dermacentor marginatus and Dermacentor reticulatus ticks to humans. Diag Microbiol Inf Dis. 2013; 76(3): 387-389.

14. Bursali A, Keskin A, Tekin S. Ticks (Acari: Ixodida) infesting humans in the provinces of Kelkit Valley, a Crimean-Congo Hemorrhagic Fever endemic region in Turkey. Exp Appl Acarol. 2013; 59(4): 507-515.

15. Kiszewski AE, Matuschka FR, Spielman A. Mating strategies and spermiogenesis in ixodid ticks. Annu Rev Entomol. 2001; 46: 167-182.

16. Bartosik K, Wiśniowski L, Buczek A. Abundance and seasonal activity of adult Dermacentor reticulatus (Acari: Amblyommidae) in eastern Poland in relation to meteorological conditions and the photoperiod. Ann Agric Environ Med. 2011; 18(2): 340-344.

17. Bartosik K, Wiśniowski L, Buczek A. Questing behavior of Dermacentor reticulatus adults (Acari: Amblyommidae) during diurnal activity periods in eastern Poland. J Med Entomol. 2012; 49(4): 859-864.

18. Balashov YS. Blood sucking ticks (Ixodidae)- vectors of diseases of man and animals. Misc Publ Entomol Soc Am. 1972; 8: 161-376.
19. Buczek A, Bartosik K, Zając Z, Stanko M. Host-feeding behaviour of Dermacentor reticulatus and Dermacentor marginatus in mono-specific and inter-specific infestations. Parasit Vectors 2015; 8: 470.

20. Bartosik K, Buczek A, Borzęcki A, Kulina D. Study of the non-parasitic stage in Ixodes ricinus after co-feeding with Dermacentor reticulatus in three infestations. Ann Agric Environ Med. 2017; 24(1): 93-98.

21. Bartosik K, Buczek A. The impact of intensity of invasion of Ixodes ricinus and Dermacentor reticulatus on the course of the parasitic phase. Ann Agric Environ Med. 2012; 19(4): 651-655.

22. Bowessidjaou J, Brossard M, Aeschlimann A. Effects and duration of resistance acquired by rabbits on feeding and egg laying in Ixodes ricinus L. Cell Mol Life Sci. 1977; 33(4): 528-530.

23. Kocan KM, Goff WL, Stiller D, Claypool PL, Edwards W, Ewing SA, Hair JA, Barron SJ. Persistence of Anaplasma marginale (Rickettsiales: Anaplasmataceae) in male Dermacentor andersoni (Acari: Ixodidae) transferred successively from infected to susceptible calves. J Med Entomol. 1992; 29: 657-668.

24. Otranto D, Dantas-Torres F, Giannelli A, Latrofa MS, Cascio A, Cazzin $\mathrm{S}$, et al. Ticks infesting humans in Italy and associated pathogens. Parasit Vectors 2014; 7: 328.

25. Pennisi M-G, Persichetti M-F, Serrano L, Altet L, Reale S, Gulotta L, et al. Ticks and associated pathogens collected from cats in Sicily and Calabria (Italy). Parasit Vectors 2015; 8: 512.

26. Geurden T, Becskei C, Six RH, Maeder S, Latrofa MS, Otranto D, Farkas R. Detection of tick-borne pathogens in ticks from dogs and cats in different European countries. Ticks Tick Borne Dis. 2018; 9(6): 1431-1436.

27. Oliver JH. Tick reproduction: sperm development and cytogenetics. In: Obenchain FD, Galun IR, editors. The Physiology of Ticks. Oxford: Pergamon Press; 1982. p. 245-275.

28. Oliver JH, Dotson EM. Hormonal control of molting and reproduction in ticks. Am Zool. 1993; 33(3): 384-396.

29. Oliver JH, Brinton LP. Cytogenetics of ticks (Acari: Ixodoidea). 7. Spermatogenesis in the Pacific Coast tick, Dermacentor occidentalis Marx (Ixodidae). J Parasitol. 1972; 58(2): 365-379.

30. Wang H, Henbest PJ, Nuttall PA. Successful interrupted feeding of adult Rhipicephalus appendiculatus (Ixodidae) is accompanied by reprogramming of salivary gland expression. Parasitology 1999; 119(2): $143-149$.

31. Ebel G, Kramer L. Duration of tick attachment required for transmission of Prowasan virus by deer ticks. Am J Trop Med. Hyg. 2004; 71(3): 268-271.

32. Richards SL, Langley R, Apperson CS, Watson E. Do tick attachment times vary between different tick-pathogen systems? Environments 2017; 4: 37.

33. Alekseev AN, Chunikhin SP. The experimental transmission of the tick-borne encephalitis virus by ixodid ticks (the mechanisms, time periods, species and sex differences). Parazitologiia 1990; 24(3): 177-185.

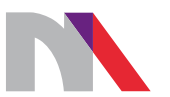

Ministry of Science and Higher Education

Republic of Poland

Generation of the DOI (Digital Object Identifier) - task financed under the agreement No. 618/P-DUN/2019 by the Minister of Science and Higher Education 